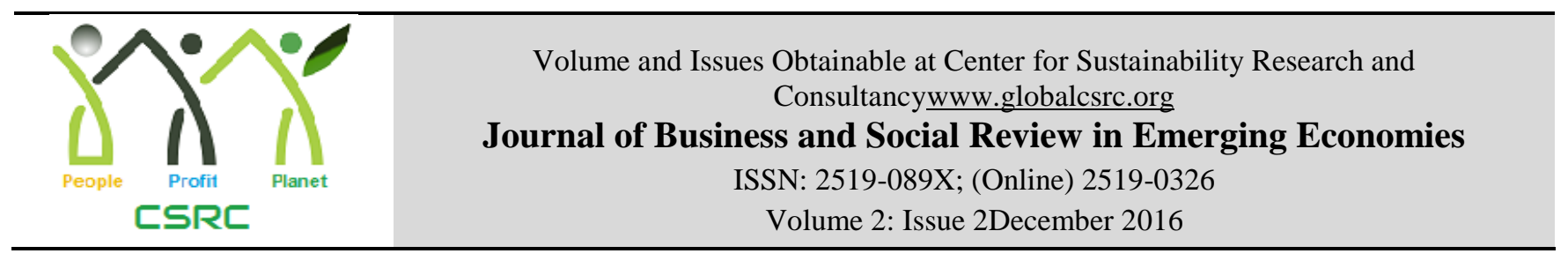

\title{
Mentoring and Organizational Performance: A review of effects of Mentoring on Small and Medium enterprises
}

\author{
${ }^{1}$ Muzaffar Hussain Shah, ${ }^{2}$ Abdul Rahim bin Othman, ${ }^{3}$ Mohd Najib bin Mansor \\ 1Muzaffar Hussain Shah, Universiti Utara Malaysia, Email: bukhari941@ gmail.com \\ 2Abdul Rahim bin Othman, Universiti Utara Malaysia \\ 3Mohd Najib bin Mansor, Universiti Utara Malaysia
}

\begin{tabular}{ll}
\hline ARTICLEDETAILS & ABSTRACT \\
\cline { 2 - 3 } $\begin{array}{l}\text { Revised format: Nov 2016 } \\
\text { AvailableOnline: Dec 2016 }\end{array}$ & $\begin{array}{l}\text { Mentoring has gained substantial attention in small and medium enterprises } \\
\text { in recent years due to its high impact on business performance. Several } \\
\text { studies have delineated the impact of mentoring on small and medium } \\
\text { enterprises and found mentoring is helpful for improving organizational } \\
\text { performance and transferring information from experienced entrepreneurs }\end{array}$ \\
$\begin{array}{l}\text { Keywords } \\
\text { to inexperienced or les experienced entrepreneurs which leads to higher } \\
\text { Mentoring, }\end{array}$ & $\begin{array}{l}\text { productivity of organization, better job satisfaction, and retention of } \\
\text { workers. This study reviews the literature of mentoring and the } \\
\text { components of mentoring. Findings of the study depict that mentoring has }\end{array}$ \\
JEL Classification: & $\begin{array}{l}\text { a positive impact on business performance. Moreover, the results also } \\
\text { implicate significant decision-making suggestions for SMEs that improved } \\
\text { L25, L29 }\end{array}$ \\
business performance can be achieved by enabling efficient mentoring \\
programs. These programs would benefits employee as well as the \\
organization. Mentoring programs not only increase the value of \\
employees but also the effectiveness of the business.
\end{tabular}

(C) 2016 The authors, under a Creative Commons Attribution-

NonCommercial 4.0

\section{Introduction}

Mentoring has gained a substantial attention in small and medium enterprises (SMEs) recent years due to its high impact on business performance and increasing positive behaviors in workers and reducing negative behaviors. Mentoring also assisted to develop healthier behaviors among workers, and improved social relationship and behavioral outcomes within the organization. Mentoring programs however demonstrate a strategy for academic staff, organizational employee and sports man etc. Career mentoring takes place within the business field, where an experienced entrepreneur educates or train inexperience/low experience entrepreneur or worker. In academic mentoring a professor/teachereducate student through their knowledge. The primary purpose of these types of mentoring istransfer of *Corresponding author's email address: bukhari941@gmail.com

Recommended citation: Shah, H. M., Othman, B. R. A.,Mansor, B. N. M.(2016). Mentoring and Organizational Performance: A review of effects of Mentoring on Small and Medium enterprises, Journal of Business and Social Review in Emerging Economies, 2(2)143-158. DOI: https://doi.org/10.26710/jbsee.v2i2.31 
information or knowledge from experience to inexperience/low experience person.

Moreover, mentor is described as being a volunteer, protector, preceptor trainer, advisor, advocate, counselor, confidant, consultant and cheerleader(Inzer, \& Crawford, 2005). Whereas mentoring can hold a range of meanings and the terminology which shows various set of fundamental assumptions. For instance, literature reveals youth mentoring has been related with programs aiming at teaching, coaching, tutoring, volunteering, counseling, role modeling, and advising(Sachdeva, \&Malhotra, 2015). Mentee may also have a similar range of terms as apprentice, protégé, aspirant, client, pupil(Wisker, Exley, Antoniou, \& Ridley, 2013). The process itself explain multifariously as „helpingee, „reciprocal ${ }^{e e}$, „leadingee, ,,advising ${ }^{\text {ee }}$, or ,,assist ${ }^{\text {ee }}$ as ,,a collaborative enterprise ${ }^{\text {ee }}$ with „learning process ${ }^{\text {ee }}$,shared ideals by which the mentor leads by illustration. Generally, in mentoring relationships knowledge and understanding about the processes remains at a preliminary stage.

The current study outlinesthe importance of mentoring program within a small and medium sized enterprise (SME). To select this particularsmall and medium size industry has some reasons. Firstly, small and medium enterprises arekey drivers of economic development and prosperity and the importance of small and medium enterprises to the world economy is overpowering, in this regard; some statistics indicated that SMEs represents about $90 \%$ of the total firms in most of the world economies, in high income countries theircontribution to the GDP is over 55\% and total employment is over 65\% (Subhan, Mehmood, \&Sattar, 2013). In addition to that, in low income countries the contribution of small and medium enterprise is $60 \%$ to the GDP and $70 \%$ of the total employment and in middle income country their contribution is $70 \%$ to GDP and $95 \%$ in total employment emanate from SMEs and informal enterprises (Subhan, Mehmood, \&Sattar, 2013). Furthermore, SMEs contribute around 55\% of the world's GDP as well as contribute significantly to the GDPs of many countries. For instance, SMEs contribute towards 85\% of the United Kingdom"s economy (Brammer, Hoejmose, \&Marchant, 2012) and 51\% of the GDP in United Stat of America (Weiss\& Welsh, 2013). Whereas, Zhu, Wittmann and Peng (2012) reported that the contribution of SMEs is more than $60 \%$ in China. In Pakistan, over $90 \%$ of all private enterprises employing up to 99 persons employ nearly $78 \%$ of the nonagriculture labor force, they contribute over 30\% to the GDP (Subhan, Mehmood, \&Sattar, 2013).Zimmer and Scarborough (1994) reported that this century will begin with the remarkable number of small industries ever, and in Pakistan, over the last decades the increase in small businessis almost 100\%(Pakistan Economic Survey 2013-14).

Secondly, the importance of this sector is at front of scholares, practitioners, academicians and policy makers but still there is a lack of existing literature on the effects of mentoring on SMEs and their workers. Majority of the researchers have focused on larger organizations, for instance, according to government of Pakistan investment at industrial level is entrepreneurship (Subhan et al., 2013).In addition, the past research shows that Pakistan ${ }^{\text {ee }}$ small and medium industry taking slow advantageas compare toother developing and developed countries like, Malaysia, China, US and Japan.Consequently, according to Hill (2001) researchers are slowly moving towards SME ${ }^{\text {ee }}$ research agenda.

Thirdly, to examine the effects of mentoring intervention this type and size of industry can provides highest opportunity, and choose of this type of organization keep away from the complexities that larger organizations inherently possess. In addition, SMEs provide services and supplies not only to customers of a locality but also act as supplier and distributor to the big business (Perks \& Oosthuizen, 2013). Moreover, the innovative ideas and product \& services creation not only reinvigorate the economy but also fills the supply and demand.

The literature review on mentoring programs among small and medium enterprises is 
scarce and lessor attention hasto pay by the researchers on this domain. Thus, to deal with this gap thisstudy proposed to look at the effect of mentoring, on business performance. The offered literature describes a real need for a study which can facilitate the owner/managers of small businesses to retain their business performance by holdingmentoring programs in their organization. The current study reviews the history of mentoring and various concepts of mentoringand its uses in the youth, academia and especially in business programs,mentoring programs are commonly used for transferring knowledge increasing positive behavior of workers towards job and for increasing the performance of businesses.

\section{Literature reviewon Mentoring}

The concepts of mentoring programs are familiar to many in apprenticeship programs and educational institutions(Ojokuku\&Sajuyigbe, 2015). Mentoring programs have been introduced for youth, new teachers, faculty and students and in business organizations. The phenomenon called mentoring is not a new trend and can be traced back to ancient Greek mythology (Rodd, 2012). Over two thousand years ago, the concept of mentoring was mentioned by Homer in The Iliad. As the adventurer Odysseus prepared to depart for the siege of Troy, he assigned a warden, Mentor, to watch over his home. After one decade, mentor acted as a faithful and dependable advisor, friend, teacher, and surrogate father to Telemachus, son of Odysseus. This narrative is one of the first attempts to facilitate discussion on the concept of mentoring. Even today, individuals can recognize someone who had a momentous impact on their education, learning and development. Such influences come "in many guises: teachers, bosses, coworkers, and friends" (Rodd, 2012; Darwin, 2000, p. 197).

\section{Relevant Definitions of Mentoring}

Defining mentoring, however, has presented a challenge within the research literature because of a "lack of any one comprehensive, yet functional, definition" (Bogat\&Redner, 1985, p.851). In addition, mentoring is a diverse process that is ever-changing and the definition of mentoring has taken on various forms and contexts over the years.

A deliberate pairing of business professionals (whether mentor-to-protégé, trainer-to-trainee, or peer-topeer) that is follow to construct the skills, competencies,abilities that will grow the business (Hankin, 1996; Hill \& Levenhagen, 1995). Furthermore, mentoring can be considered the "nurturing process in which a more skilled or more experienced person, serving as a role model, teaches, sponsors, encourages, counsels, and befriends a less skilled or less experienced person for the purpose of promoting the latter's professional and/or personal development" (Anderson and Shannon, 1988, p.40). Accordingly, Noe (1988), "The mentor is usually a senior, experienced employee who serves as a role model, provides support, direction, and feedback to the younger employee regarding career plans and interpersonal development and increases visibility of the mentee to decisions-makers in the organization who may influence career opportunities" (p.458). Individuals are committed to proving support in an attempt to help remove barriers that may exist within an organization (Hunt \&Micheal 1983; Kram, 1985). Mentors have often been theorized as those persons who rely on a deep knowledge base to educate and guide others (Swap, Leonard, Shield, and Abrams, 2001). One-to-one relationship among mentor and mentee is familiar now a day in mentoring programs where experienced persons transfer their knowledge, experience to inexperience/low experience persons (Okurame\&Balogun, 2005). This mentoring relationship can also be define, "A deliberate pairing of a more skilled or experienced person with a lesser skilled or experienced one, with the agreed-upon goal of having the lesser skilled person grow and develop specific competencies (Murray, 2006)." This definition seems to allowthat it is possible that a mentor can be younger than mentee. Additionally, mentoring consist of sharing experience, listening with empathy, developing insight through reflection, professional friendship, and encouraging (Sachdeva, \& Malhotra, 2015). 
It is difficult to identify when mentoring research began. However, literature would support that Kram's dissertation and subsequent work provided the foundation for the beginning of comprehensive mentoring research. Mentoring has also been studied from various research directions (Selladurai, 2014). These directions include exploring the phases of mentorship (Kram, 1983; Noe, 1988 ; Mishra, \& Jain, 2014), outcomes of mentorship (Allen, \&Eby, 2011; Tracy, et al, 2015) and functions served by the mentor (Chen, 2013).

\section{Phases of mentoring}

Phases of mentoring are important because of the developmental process that occurs throughout each of the phases. (Kram 1983; Mishra, \& Jain, 2014; Revelo, \& Loui, 2015) were propose the four phases of mentoring: Initiation, Cultivation, Separation, and Redefinition. The Initiation phase usually occurs during the first six to twelve months. During this time the mentorship forms. According to Chao (1997), "through initial interactions that involve junior and senior organizational members, a prospective mentee begins to respect the competence of a potential mentor..." (p. 16). Further, the potential mentor begins to notice the mentee and believes that he or she deserves guidance and coaching. As the relationship becomes more powerful and strengthens, it transpires into the Cultivation phase. Depending on the nature of the relationship, this time period can last from two to five years. The mentee and mentor "learn more about each other's capabilities and optimize the benefits of participating in mentorship" (Chao,1997, 1997, p. 16). Mentoring functions (i.e. psychosocial and career) are maximized during this phase. The Separation phase is characterized by the breaking apart of the relationship (for positive or negative reasons). Depending on the nature of the relationship, this phase can generally last from six to twenty-four months. This process is both a physical and psychological separation for the mentee and mentor. Further, it can evoke a number of emotions, including anxiety, defiance, or stress (Chao, 1997). The Redefinition phase terminates the mentoring relationship. The mentor- mentee relationship becomes more of a "peer like friendship" (p. 16). This period has no specified length. It has been suggested that career functions usually emerge first in mentoring relationship development (Kram, 1985). As the mentor and menteeprogress through the phases, psychosocial support becomes more essential and valuable to the mentees (Son, \& Kim, 2016).

\section{Functions of Mentoring}

Mentoring relationships have been shown to provide two distinct functions for mentee: career support function and psychosocial support function. These functions were initially defined by Kram (1985) and have been extensively explored by and supported by researchers (Ragins\& Cotton, 1999; Chao, Walz, \& Gardner, 1992; Scandura, 1998; Kwan, \&Yim, 2011; Uy, Foo, \& Song, 2013; de Janasz, Behson, Jonsen, \&Lankau, 2013). Further, these two functions have been the subject of subsequent measurement and validation work (Uy, Foo, \& Song, 2013:Noe, 1988). Studies exploring the dimensionality of mentoring provide support for the existence of career and psychosocial functions. Career functions are directly related to assisting the mentee with career advancement. These functions include providing a mentee with opportunities for increased exposure and visibility within an organization,sponsorship, coaching and challenging assignments (Chao, 1997; St-Jean, \&Audet, 2012). Psychosocial functions, however, focus more on the personal aspects of the mentee that influence the mentee self-image and competence. Mentors providing psychosocial functions usually have an emotional bond with the mentee and provide role modeling, counseling, friendship and confirmation. In addition, Craig et al. (2013) suggested that these two functions of mentoring can influence employees to experience other beneficial organizational outcomes. Confidence, effectiveness and competence are often enhanced by participation in mentoring relationships that function to meet the career and psychosocial needs of the mentee. 


\section{Career Support of Mentoring}

Career functions are directly related to assisting the mentee with career advancement. Career support function (e.g. coaching, exposure, visibility, protection, challenging assignments) are geared more toward an organization performance and the individual's career. Research findings support significant relationships between functions of mentoring and employee outcomes and organizational performance. Furthermore, a strong relationship was investigated among functions related to career and outcomes of intrinsic job satisfaction. Lastly, in a study made on the employees of Britain during the time span of six month employment, researchers measured the two mentoring functions (Orpen, 1995). Career functions and the outcome measures (i.e. promotion and salary growth) were significantly correlated. However, the associations between psychosocial functions and output were not significant (Gentry \&Sosik 2010). Subsequently, organizational rewards for mentee who receive career-related mentoring support tend to be higher. These rewards can be interpreted as benefits of mentoring. Gentry and Sosik (2010) reported that career-related support and psychosocial support can be viewed as first-level outcomes of mentorships. It was suggested that these two supportive functions of mentoring can influence employees to experience other beneficial organizational performance. In addition, according to St-Jean and Audet (2012) career support is directly related to assisting the mentee with career advancement. These supportive functions include providing a mentee with opportunities for increased exposure and visibility within an organization, sponsorship, coaching and challenging assignments, these both supportive functions are helpful for the increasing the performance of small business.

\section{Psycho-social Support of Mentoring}

Mentoring is considered a relationship which is trusted and is between new entrepreneur and the old or experienced one, where the role of the old one is considered as a role model and act as a guide by making suggestions and advice to the new one as he or she attempts entrepreneurial tasks, achieve organizational goals, and increase organizational performance (St-Jean \&Audet, 2009; Teeratansirikool et al., 2013). Mostly, mentors are considered old, wise and experienced in the relevant field of the mentees where guidance and support is needed. For mentorship, the basic benefit is to gain experience and knowledge the mentor has experienced which helps in the extension beyond the particular region (Robinson, \&Reio, 2012). In the psychological, career, and in emotional support, the benefit of extensive mentoring occurs (Baranik et al., 2010; St-Jean, \&Audet, 2012). The different needs of mentees are known to the experienced mentor; however, they have similar objective and that is the achievement of the professional goals which are desired (Hays, 2013). During the interaction with the mentor, emotional and psychological support is desired by mentees (Chun, Sosik, \& Yun, 2012). The mentor provides psychological support to the mentee through friendship, coaching, counseling and acceptance (Hu, Wang, Yang, \& Wu, 2014).

\section{Research Areas of Mentoring}

Research on the concept of mentoring occurs in three major areas: academic mentoring,youth mentoring and business mentoring (Eby, et al., 2008). Kammeyer-Mueller and Judge (2008) conducted a review of mentoring research in the PsycINFO database (1887-2007) and identified approximately 3,175 abstracts across these areas that referenced the terms "mentor", "mentoring" or "mentorship". The focus of these studies varied and included, among others, research studies that focused on differences between mentee and non-mentee career-related outcomes and observed benefits among relationships of mentor and mentee. Even though the scale is much smaller, research on mentoring in SMEs is as diverse as the general mentoring research literature.

\section{Youth Mentoring}

Group mentoring offer services to the youth in schools and in youth organizations. Critical adults have 
been guided by these organizations in children lives in form of teachers, youth volunteer"es and others (Matz, 2015). Adults who avoid one-to-one meeting are mostly feeling comfortable in group mentoring. Individuals mentoring program are often considered hefty due to limited risk groups or safety issues, while group mentoring program attracts such mentors (Lakind, Atkins, \& Eddy, 2015). Daylight or early evening group mentoring sessions in schools or incommunity centers make it more attractive to older volunteers, who resides near to community centers, schools and churches. Mentoring literature review highlight that most of the individual volunteers are female (Corney, 2016), who were less educated and belong to low income level group. Individuals involve in one to one mentoring are less attract toward group mentoring that is why the number of retirees and minorities high in group mentoring programs. Those volunteers are welcomed who feel comfortable in meeting with children in public settings or in groups such as schools, community centers, and churches. volunteers share their experience and most of them prefer to arrange group mentoring session due to specific activities and structures so it"s helps them to save substantial time commitment for one to one mentoring in this way. Group mentoring attract youth from different ethnic or racial minority groups (Matz, 2015). Response rate toward group mentoring is high due to its compatible level in Aboriginal and Asian settings. Hence, the vast majority of youth respond that the nature of the relationship between mentor and youth in groups are not satisfactory and they don "t have feeling to interact one-to-one sessions with mentor. Well, peers group setting are more attract the majority of youth.

In research streams youth mentoring is the most isolated one, relationship between volunteer adult and younger mentee at risk, when particularly focus on the effort to control the truancy, drug use, and gang violence. Training youth in jobs through mentoring programs are formally existed since the post-world war II period. Hamilton \& Hamilton (1992) explain the concept of mentoring or apprenticeship as the activity through which youth can be trained by a profession scholar or practitioner who teaches them art, skill or trade in a practical way. In traditional mentoring style trainee get training for specific period of time through agreement between employers. During the post-world War II the key inspiration for male children from the working class families to get apprenticeship and learning a trade (Vickerstaff, 2007). Researchers regularly find positive and powerful influences from mentoring on the professional and personal development of graduate students, both in terms of their objective successes and their subjective satisfaction. Jacobi (1991) noted that mentoring involvement could be the one of the most important predictors of student satisfaction, and others have stressed that mentoring is critical for a

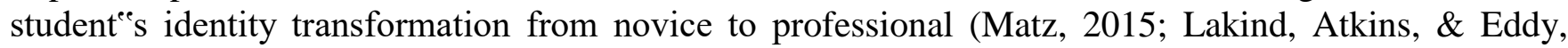
2015). While students appear to need psychosocial functions more than career functions (Allen, Russell, et al., 1997), mentors also exert an enduring and important effect on a student ${ }^{\text {ee }}$ s cognitive beliefs and future practices (Evertson\& Smithey, 2000): so much so that Russell \& Adams (1997) called finding a mentor "a major developmental task of the early career" (p. 3) due to the centrality mentoring can play in the beginning stages of a professional se work-life. Allen (2004) told participants that the purpose of the experiment was to inform a mentoring program between university personnel and high school students, moving close to the realm of youth-mentoring. Youth mentoring outcomes have not been as powerful as those found in academic mentoring, likely because youth aged protégés endure many other non-mentoring influences on their development (Eby, Allen, et al., 2008).

\section{Academic Mentoring}

Academic or educational research focuses on the individuals involved in the process more than at the surrounding organization, with long-term learning goals, professional career results, and recruiting and retaining teaching professionals as the outcomes of interest. Among the various mentoring arenas, the beneficial outcomes of mentoring have been strongest in academic relationships (Eby, Allen, et al., 2008). In an academic setting, performance goals should refer to conducting research, publication productivity, and the reception of awards. One of the most critical components of mentoring programs 
for new teachers is the relationship between the new teacher and their mentor, often anexpert teacher. The mentor teacher provides crucial support and advice to new teachers in areas of classroom management, lesson planning, pedagogy and emotional support (Brill \& McCartney, 2008). Mentoring also positively affects the mentor or veteran teacher by expanding upon their teaching skills and leading to the development of new skills (Odell \& Ferraro, 1992). A study conducted by (Ingersoll, 2003) reported that around 40 to 50 recent teachers leave the career completely within the first five years of job. Furthermore, Ingesoll reported that mentoring has decreasing a turnover rate from 40 percent to 18 percent in the School and Staffing Survey given to beginning teachers in 1999.

Only well-organized mentoring programs can positive effect on teachers (Brill \& McCartney, 2008). Badly structured and operated mentoring programs for new teachers create more stress, lower career expectations, and are exhausting to mentees usually due to an ineffective and poorly trained mentor (Smethem, \&Youens, 2007).

\section{Mentoring in Business}

Over the last few years, mentoring has become more widely recognized as an effective tool for increasing retentionwithin the SME"s context. According to Gray et al. (2011) the concept within entrepreneurial studies, i.e. business mentoring has emerged in SMEs concept. Researchers suggest that, in today's employment settings, the need for mentoring is greater than ever (Dougherty, Turban, \& Haggard, 2007). Organizations understand and appreciate the importance of technology in daily operations. People, however, continue to be the most important component of many organizations. Organizations are in need of consistent professional and personal skill development for mastering the complex issues and changes of the work environment (Dew, Alan, \& Tomlinson, 2008). Mentoring has been considered attractive and low cost strategy in the today"s organizational complexity in order to enhance and make the workforce skilled (Murray, 2002). Organizations are also under a tremendous amount of strain from both external and internal entities "for the sustainability of competitive edge with the help of cost reduction and enhancement of efficiency and performance (Murray, 2006). An ongoing point of interest is that of determining the benefits of mentoring and whether mentoring can be an effective tool in increasing retention levels among small and medium enterprises.

However, in line with the above debate mentoring involves a plethora of unique possibilities and experiences that impact the fundamental aspects of an organization and its impact both internally and externally. While the person is in the crucial stage of development, the mentor is supposed to act like a guide and is supporting a developing novice or inexperience (Weng et al., 2010). With the help of mentoring, psychological well-being, the self-image and emotional adjustment are improved (Koyuncu et al., 2014). The entrepreneurs can enhance their knowledge regarding the identification of errors made in the last made decisions and considered the necessary changes for the purpose of being sustained and increasing the market share (Dew, Read, Sarasvathy, \&Wiltbank, 2009). Similarly, the high degree of complexity, such as designing a successful business system, hiring competent employees, identifying and selecting prospective customers, validating new products, and negotiating business contracts and payment terms makes it necessary for inexperience/low experience entrepreneurs to have experienced mentors (St- Jean \&Audet, 2009). The lack of experience and competencies also makes it difficult for inexperience/low experience entrepreneurs to avoid costly mistakes during the most difficult and intense period of the business cycle.

The professional support is extended by mentors in the form of career support,emotional support, and role modeling support to the inexperience/low experience entrepreneurs, these supports are helpful for the success of organizations (McGregor \& Tweed, 2002; St-Jean, \&Audet, 2012; Hayward et al., 2010). With the help of mentorship program a mentors can guide and shape the behaviors of mentee (Pompa, 
2012). Acceptance, counseling, coaching, and friendship are included in emotional, social, and psychosocial support and is a part of the mentor"s responsibility (Robinson, \&Reio, 2012; Chun et al., 2012).In line with the above debate, mentoring is deemed to be an innovation in improving the performance of organizations.

Pertaining to the relationship between mentoring and business performance various researchers conducted studies in this perspective. For instance, Muchau (2013) conduct a study with 91 samples had conclusion that mentorship program is a strong predictor of business performance. Another study conducted by Sherifat (2013) used 50 small- scale enterprises in his study and point out that mentoring is clearly very important to women, as well as encouragement and financial support of their small-scale business. Similarly, the results from 630 small companies show a direct relationship has been found between mentoring and the performance of businesses (Núñez- CachoUtrilla, \& Grande Torraleja, 2013). Moreover, a study conducted by Brien, and Hamburg (2014) reported that organizations are assisted by training in the establishment and sustainability of competitive advantages with the help of enhancing quality, productivity and financial results. According to Lee, and Feldman et al., (2012) the organizational performance also increases with the prosperity of mentoring in Taiwan.

\section{Benefits of businessMentoring}

Pertaining to the relationship between mentoring and business performance various researchers conducted studies in this perspective.According to Garvey and Garret-Harris (2008) mentoring has been considered emerging in the previous years and the literature consistently reports mentoring is to be a valuable tool in both business and personal enhancement, there are some studies or reports making references of specific measureable advantages and influences. The study of Northern Ireland ${ }^{\text {ee }}$ s Bridge mentoring program LEED Unit (2006) investigated various economic advantages for SMEs on the scheme comprising: increased sales turnover, increased after-tax profits and increased employment.

The study of Garvey and Garrett-Harris (2008) reviewed100 previous studies and then made an observation of the scheme of mentoring in the limit of industry sectors. Considering the observation on various references ofadvantages mentioned by beneficiaries, the documented the most known benefits of mentor, mentees agencies and organization enhancement as follow:

Firstly, there are some advantages for mentees comprising: enhancement of performance, increased productivity, opportunity of career and making advancement, enhancement of skill and knowledge, more confident, enhancement in the satisfaction of job, wellbeing, and motivation, decision making skills, abilities of leadership, developing leaders, making understanding related to product, customer, policies and politics, enhancement of creativity and innovation, and encouraging taking positive riskand development of cognitive learning is increased beyond the domain of career and personal life $(\mathrm{Hu}$, Wang, Yang, \& Wu, 2014), according to Mitchelmore and Rowley (2010) for firm performance, the most influential factors are skills, technical understanding, and both psychological and behavioral features. The self-image of mentee can be enhanced by psychological support with the help of ensuring the desired behaviors which help in the development of mentee ees moral outlook, capability of leadership, professional identity, and the efficacy of taking risk, personal competence and confidence level (St-Jean \& Tremblay, 2011). However, the relationship of mentoring which not help in the enhancement of learning will be considered dysfunctional (Kumar et al., 2013). Although, to novices, the strategies of self-management can be considered advantageous, who have desires related to the future outcomes of entrepreneurship, the operation of a profitable venture is considered difficult to the new entrepreneurs and will feel a need of mentoring for further guidance (Petkova, 2009).

Secondly, the mentor related benefits are: enhancement of performance with the help of improved 
knowledge, sales and networking, more confidence, intensive practices of business, professional identity, positive attitude to change, increased ideas generation and knowledge enhancement; greater job satisfaction, fulfillment of human psycho-social needs; improved communication; opening up of new job opportunities and advances in career; loyalty and self- awareness; rejuvenation and improved motivation.

The benefits enjoyed by organization in which mentee is empowered are: reduced labor and training costs; help in managing talent; improved retention rates and reduced staff turnover, cultivating loyalty and commitment; developing the culture and help in disseminating business values; improved business stability; improved morale, motivation and relationships; improved succession planning; improved job creation and business performance; provided cost efficient enhancement; enhanced productivity; encouraging older managers, enhanced flow of information and communication; improving business learning.

\section{Mentoring and Resource base view theory}

Even though the performance of small and medium enterprise is widely studied (Daud\&Yusoff, 2010; Gaur, Mukherjee, Gaur, \&Schmid, 2011; Kreiser, Marino, Kuratko, \& Weaver, 2013; Naudé, Zaefarian, NajafiTavani, Neghabi, \&Zaefarian, 2014; Pett\& Wolff, 2011; Pratono\& Mahmood, 2014; Rosenbusch, Brinckmann, \& Bausch, 2011; Sok, O'Cass, \&Sok, 2013; Stam, Arzlanian, \&Elfring, 2014; Bozionelos, 2015), study related to small business performance is still under discussion that what should be the basic constructs that affect the performance. The personality of the entrepreneur is often perceived by practitioners as one of the most fascinating topics in the field of entrepreneurship which may have positive impact to increase the performance of organization (Delmar, 2000). Some believe that a successful entrepreneur is a result of the special set of personal abilities and characteristics, rather than other factors and these factors heavily effect on organization performance.

Building on resource base viewtheory, this current study has aim to explore the relationship and impact of mentoring on small business performance. Mentoring has so many advantages related to mentee and organizational performance directly and indirectly bytransferring information and knowledge assembles through many years of experience (Masalimova, \&Sabirova, 2015). The literature on mentoring has been rarely examined for implication and for outcomes. Yet, their focal concepts hold much promise for detailing how strong cultures that constitute unique resources can develop (Barney, 1986b). The aim of this current study on mentoring is foundation forSME ${ }^{e e}$ s learning and RBV theory. By constructing literatures, study proposed knowledge creationand learning for strategic decision making for organization (Lyles and Schwenk, 1992),cognitive maps or knowledge structures are critical for organization to react to environmental turbulence (Gnyawali\& Stewart, 2003). Mentoring programs aid to creating and improving knowledge of the competitive environment.Organization able to making effective strategic decisions byusing knowledge providing by mentor (Srivastava and Grant, 1985).Mentoring providing valuable benefit for most important elements of human capital inside the organization. Offstein, Shah and Gnyawali (2011); Núñez-CachoUtrilla, and Grande Torraleja (2013) also used resource based theory in their studiesfor principal relationship between mentoring and firm performance.

\section{Implementation and future research}

The current study has aid to set a base for the study of mentoringand small business performance. The current study is generating more information, knowledge and arguments on mentoring in small and medium enterprises to enhance the performance. Furthermore, this study is also contributing to the literature on the relationship of mentoring and small business performance. The paper explored the 
phases and forms of mentoring that will help SMEs to become skillful for the safety of their future and emerging needs.

Moreover, this study has explored the role of mentoring inyouth, academia and business with a specific focus on positive factors which enhances the performance of organization, literature explore the positive effects of mentoring in organizations such as, mentoring reduced labor and training costs(Marc, 2015, July 21; Emelo, 2015, June Wednesday), help in managing talent, reduced staff turnover and improved retention rates(Rockoff, 2008), help in disseminating business values and developing the culture, improved business stability, improved morale, motivation and relationships, improved succession planning, improved job creation and business performance, provided cost efficient enhancement, enhanced productivity, encouraging older managers, enhanced flow of information and communication, improving business learning. Especially in business performance, The study of Northern Ireland ${ }^{\text {ee }} \mathrm{s}$ Bridge mentoring program LEED Unit (2006) findings indicated that mentoring has various economic advantages for SMEs i.e. increased sales turnover, increased after-tax profits, increased employment and successful business strategies to grow ventures on their own. In addition, organization gains more benefits in terms of facilitation of partnerships, strategic change, problem solving, innovation and change, and better project management.

The most important and positive factor of mentoring program related to mentees advantages in business organizations has been explored from the past review papers which are comprising: enhancement of performance(Askari et al., 2015), increased productivity, opportunity of career and making advancement, enhancement of skill and knowledge, more confident, enhancement in the satisfaction of job, wellbeing, and motivation, decision making skills, abilities of leadership, developing leaders, making understanding related to product, customer, policies and politics, enhancement of creativity and innovation, and encouraging taking positive risk.

Literature review shows that mentoring has so many advantages to the mentee and organization, the question is still unanswered why more businesses are not holding mentor programs into their organization for human resource training, operational structure and development programs. These advantages are not considered quantified but were used frequently and proved that the researcher resulted that on the nature there is an agreement of advantages related to mentoring. The concept of mentoring is not new but in business context it has not been widely explored, it may have some reasons like, lack of consultants, trainers or advisers available with information or knowledge on how to demonstrateor train the mentee by mentoring programs. Furthermore, for mentoring program in business research is necessary to establishthe return on investment.

\section{Reference}

Allen, T. D., \&Eby, L. T. (2004). Factors related to mentor reports of mentoring functions provided: Gender and relational characteristics. Sex Roles, 50(1-2), 129-139.

Allen, T. D., \&Eby, L. T. (2008). Mentor commitment in formal mentoring relationships. Journal of Vocational Behavior, 72(3), 309-316.

Allen, T. D., \&Eby, L. T. (Eds.). (2011). The Blackwell handbook of mentoring: A multiple perspectives approach. John Wiley \& Sons.

Allen, T. D., Russell, J. E., \&Maetzke, S. B. (1997). Formal peer mentoring factors related to proteges' satisfaction and willingness to mentor others.Group\& Organization Management, 22(4), 488-507.

Anderson, E., \& Shannon, A. (1988). Toward a conceptualization of mentoring. Journal of Teacher Education, 39, 38-42.

Askari, L., Kamran, F., Baig, A., Askari, M. S., \&Baig, A. S. (2015). EFFECTIVE MENTORING 


\section{ENHANCES EMPLOYEE PERSONAL RESILIENCE: A COMPARATIVE STUDY ON} TELECOM COMPANIES.Pakistan

Business Review, 17(3), 624-647.

Baranik, L. E., Roling, E. A., \&Eby, L. T. (2010). Why does mentoring work? The role of perceived organizationalsupport. Journal of Vocational Behavior,76(3), 366-373.

Barney, J. B. (1986). Organizational culture: can it be a source of sustained competitive advantage?. Academy of management review, 11(3), 656-665.

Black, L. L., Jensen, G. M., Mostrom, E., Perkins, J., Ritzline, P. D., Hayward, L., \&Blackmer, B. (2010). The first year of practice: an investigation of the professional learning and development of promising novice physical therapists. Physical Therapy, 90(12), 1758-1773.

Bogart, C. A., \&Rednar, R. L. (1985). How mentoring affects professional development of women in psychology. Professional Psychology, Research, and Practice, 12, 851-859.

Bozionelos, N. (2015). Social capital and careers: Indisputable evidence and note for caution. Handbook of research on sustainable careers, 67-82.

Brammer, S., Hoejmose, S., \&Marchant, K. (2012). Environmental management in SMEs in the UK: practices, pressures and perceived benefits. Business Strategy and the Environment, 21(7), 423-434.

Brill, S., \& McCartney, A. (2008). Stopping the revolving door: Increasing teacher retention. Politics \& Policy, 36(5), 750-774.

Chao, G. T. (1997). Mentoring phases and outcomes. Journal of vocational behavior, 51(1), 15-28.

Chao, G. T., Walz, P., \& Gardner, P. D. (1992). Formal and informal mentorships: A comparison on mentoring functions and contrast with nonmentored counterparts. Personnel psychology, 45(3), 619-636. Chen, Y. C. (2013). Effect of Reverse Mentoring on Traditional Mentoring Functions. Leadership and Management in Engineering, 13(3), 199-208.

Chun, J. U., Sosik, J. J., \& Yun, N. Y. (2012). A longitudinal study of mentor and protégé outcomes in formal mentoring relationships. Journal of Organizational Behavior, 33(8), 1071-1094.

Chun, J. U., Sosik, J. J., \& Yun, N. Y. (2012). A longitudinal study of mentor and protégé outcomes in formal mentoring relationships. Journal of Organizational Behavior, 33(8), 1071-1094.

Corney, T. (2016, July). Rethinking Youth Mentoring: Limitations and Possibilities for Youth Work. In Third ISA Forum of Sociology (July 10-14, 2016). Isaconf.

Craig, C. A., Allen, M. W., Reid, M. F., Riemenschneider, C. K., \& Armstrong, D. J. (2013).The impact of career mentoring and psychosocial mentoring on affective organizational commitment, job involvement, and turnover intention.Administration \& Society, 45(8), 949-973.

Darwin, A. (2000). Critical reflections on mentoring in work settings. Adult Education Quarterly, 50(3), 197-211. Daud, S., \&Yusoff, W. F. W. (2010). Knowledge management and firm performance in SMEs: The role of social capital as a mediating variable.Asian Academy of Management Journal, 15(2), 135155.

De Janasz, S., Behson, S. J., Jonsen, K., \&Lankau, M. J. (2013). Dual sources of support for dual roles: how mentoring and work-family culture influence work-family conflict and job attitudes. The International Journal of Human Resource Management, 24(7), 1435-1453.

Delmar, F., \&Davidsson, P. (2000). Where do they come from? Prevalence and characteristics of nascent entrepreneurs. Entrepreneurship \& regional development, 12(1), 1-23.

Dew, N., Read, S., Sarasvathy, S. D., \&Wiltbank, R. (2009). Effectual versus predictive logics in entrepreneurial decision-making: Differences between experts and novices. Journal of Business Venturing, 24(4), 287-309.

Dew,D.W., Alan,G.M.,\& Tomlinson, P.(Eds.) (IRI 2008). Recruitment and retention of vocational rehabilitation counselors (Institute on Rehabilitation Issues Monograph No. 33). Washington,DC: The George Washington University, Center for Rehabilitation Counseling Research and Education. Retrieved from: http://iriforum.org/download/33IRI.pdf

Dougherty, T. W., Turban, D. B., \& Haggard, D. L. (2007). Naturally occurring mentoring relationships 
involving workplace employees. The Blackwell handbook of mentoring: A multiple perspective approach, 139-158.

Evertson, C. M., \& Smithey, M. W. (2000). Mentoring effects on proteges' classroom practice: An experimental field study. The Journal of Educational Research, 93(5), 294-304.

Feldman, M. D., Steinauer, J. E., Khalili, M., Huang, L., Kahn, J. S., Lee, K. A., ... \& Brown, J. S. (2012). A mentor development program for clinical translational science faculty leads to sustained, improved confidence in mentoring skills. Clinical and translational science, 5(4), 362-367.

Friedman, A. and Philips, M. (2004) Continuing Professional Development: developing a vision, Journal of Education and Work, 17(3), pp. 361-376.

Garvey, B., \& Garrett-Harris, R. (2008). The Benefits of Mentoring: A literature review for East Mentor"s Forum. Sheffield: Sheffield Hallam University.

Gaur, A. S., Mukherjee, D., Gaur, S. S., \& Schmid, F. (2011). Environmental and Firm Level Influences on Inter-

Organizational Trust and SME Performance. Journal of Management Studies, 48(8), 1752-1781.

Gentry, W. A., \&Sosik, J. J. (2010). Developmental relationships and managerial promotability in organizations: Amultisource study. Journal of Vocational Behavior, 77(2), 266-278.

Gnyawali, D. R., \& Stewart, A. C. (2003). A contingency perspective on organizational learning: integrating environmental context, organizational learning processes, and types of learning. Management Learning, 34(1), 63- 89.

Gray, D. E., Ekinci, Y., \&Goregaokar, H. (2011). A Five-dimensional Model of Attributes: Some precursors of executive coach selection. International Journal of Selection and Assessment, 19(4), 415428.

Hamilton, S. F., \& Hamilton, M. A. (1992). Mentoring programs: Promise and paradox. Phi Delta Kappan, 73(7), 546.

Hankin, J. N. (1996). The door that never closes: Continuing education needs of community college leaders. In A.

M. Cohen (Series Ed.), \& J. C. Palmer \& S. G. Katsinas (Vol. Eds.), Graduate and continuing education for community college leaders: what it means today (pp. 37-46). New Directions for Community Colleges, no. 95. San Francisco: Jossey-Bass.

Hays, T. (2013). The Role of Mentorship in the Training of Professional Musicians.

Hill, J. (2001). A multidimensional study of the key determinants of effective SME marketing activity: Part

1.International Journal of Entrepreneurial Behavior \& Research, 7(6), 211-235.

Hill, R. C., \& Levenhagen, M. (1995). Metaphors and mental models: Sensemaking and sensegiving in innovative and entrepreneurial activities. Journal of Management, 21(6), 1057-1074.

Hu, C., Wang, S., Yang, C. C., \& Wu, T. Y. (2014). When mentors feel supported: Relationships with mentoring functions and protégés' perceived organizational support. Journal of Organizational Behavior, 35(1), 22-37.

Hu, C., Wang, S., Yang, C. C., \& Wu, T. Y. (2014).When mentors feel supported: relationships with mentoring functions and protégés' perceived organizational support. Journal of Organizational Behavior, 35(1), 22-37

Hunt, D. M., \& Michael, C. (1983). Mentorship: A career training and development tool. Academy of Management Review, 8, 475-485.

Ingersoll, R., \& Smith, T. (2003). What are the effects of mentoring and induction on beginning teacher turnover. American Education Research Journal, 41(3), 681-714.

Jacobi, M. (1991). Mentoring and undergraduate academic success: A literature review. Review of educational research, 61(4), 505-532.

Johnson, W. B., \&Huwe, J. M. (2003). Getting mentored in graduate school. American Psychological Association. Judge, T. A., Piccolo, R. F., Podsakoff, N. P., Shaw, J. C., \& Rich, B. L. (2010). The 
relationship between pay and job satisfaction: A meta-analysis of the literature. Journal of Vocational Behavior, 77(2), 157-167.

Koyuncu, M., J. Burke, R., Alayoglu, N., \&Wolpin, J. (2014). Mentoring relationships among managerial and professional women in Turkey: Potential benefits?.Cross Cultural Management, 21(1), $2-22$.

Kram, K. E. (1983). Phases of the mentor relationship. Academy of Management journal, 26(4), 608625. Kram, K. E. (1983). Phases of the mentor relationship. Academy of Management journal, 26(4), 608-625. Kram, K. E. (1985). Mentoring at work. Glenview, IL: Scott, Foresman.

Kreiser, P. M., Marino, L. D., Kuratko, D. F., \& Weaver, K. M. (2013). Disaggregating entrepreneurial orientation: the non-linear impact of innovativeness, proactiveness and risk-taking on SME performance. Small Business Economics, 40(2), 273-291.

Kumar, S., Johnson, M., \&Hardemon, T. (2013). Dissertations at a distance: Students ${ }^{\text {ee }}$ perceptions of online mentoring in a doctoral program. International Journal of E-Learning \& Distance Education, 27(1).

Kwan, H. K., Liu, J., \&Yim, F. H. K. (2011). Effects of mentoring functions on receivers' organizational citizenship behavior in a Chinese context: A two-study investigation. Journal of Business Research, 64(4), 363-370.

Lakind, D., Atkins, M., \& Eddy, J. M. (2015). Youth mentoring relationships in context: Mentor perceptions of youth, environment, and the mentor role. Children and youth services review, 53, 52-60.

LEED Unit (2006) „Mentoring for Business in Wales: Learning from Good Practice. “ Cardiff: Cardiff Business School for Welsh Assembly Government.

Lis, L. D., Wood, W. C., Petkova, E., \&Shatkin, J. (2009). Mentoring in psychiatric residency programs: a survey of chief residents. Academic Psychiatry, 33(4), 307-312.

Lyles, M. A., \&Schwenk, C. R. (1992). Top management, strategy and organizational knowledge structures. Journal of management studies, 29(2), 155-174.

Masalimova, A. R., \&Sabirova, L. L. (2015). Mentors and Trainees Professional Interaction Features at the Modern Enterprises in Russia. Review of European Studies, 7(4), 20.

Matz, A. K. (2015). Commentary: Do youth mentoring programs work? A review of the empirical literature. Journal of juvenile justice, 4(1), 83-101.

McGregor, J., \& Tweed, D. (2002). Profiling a new generation of female small business owners in New Zealand: networking, mentoring and growth. Gender, Work \& Organization, 9(4), 420-438.

McGregor, J., \& Tweed, D. (2002). Profiling a new generation of female small business owners in New Zealand: networking, mentoring and growth. Gender, Work \& Organization, 9(4), 420-438.

Mishra, D., \& Jain, S. K. (2014). Flexibility and Sustainability of Mentorship Model for Entrepreneurship Development: An Exploratory Study. InOrganisational Flexibility and Competitiveness (pp. 25-39). Springer India. Mitchelmore, S., \& Rowley, J. (2010). Entrepreneurial competencies: a literature review and development agenda. International journal of entrepreneurial Behavior \& Research, 16(2), 92-111.

MUCHAU, N. R. (NOVEMBER 2013). THE EFFECT OF MENTORSHIP PROGRAM ON BUSINESS PERFORMANCE AMONGST MICRO, SMALL AND MEDIUM ENTERPRISES (MSMEs) IN NAIROBI

COUNTY (Unpublished doctoral dissertation). University of Nairobi.

Murray, M. (2002). Beyond the myths and magic of mentoring: How to facilitate an effective mentoring process. John Wiley \& Sons.

Murray, M. (2006). Innovations in performance improvement with mentoring. In J. Pershing, Handbook of Human Performance Technology (pp. 455-477). San Francisco: Pfeiffer.

Murray, Michael P. 2006. Econometrics: A Modern Introduction. Boston: Addison-Wesley.

Naudé, P., Zaefarian, G., Tavani, Z. N., Neghabi, S., \&Zaefarian, R. (2014). The influence of network effects on SME performance. Industrial Marketing Management, 43(4), 630-641. 
Noe, R. A. (1988). An investigation of the determinants of successful assigned mentoring relationships. Personnel psychology, 41(3), 457-479.

Núñez-CachoUtrilla, P., \& Grande Torraleja, F. Á. (2013).The importance of mentoring and coaching for family businesses.Journal of Management \& Organization, 19(04), 386-404.

Núñez-CachoUtrilla, P., \& Grande Torraleja, F. Á. (2013).The importance of mentoring and coaching for family businesses.Journal of Management \& Organization, 19(04), 386-404

Odell, S. J., \& Ferraro, D. P. (1992). Teacher mentoring and teacher retention. Journal of Teacher Education, 43(3), 200-204.

Offstein, E. H., Shah, A. J., \&Gnyawali, D. R. (2011). Effects of CEO-BOD mentoring on firm competitive behavior. Review of Business, 32(1), 75.

Ojokuku, R.M \&Sajuyigbe, A.S (2015).Impact of Mentoring on Career Development of Academics in Nigerian Universities

Okurame, D. E., \& Balogun, S. K. (2005). Role of informal mentoring in the career success of first-line bank managers. Career Development International, 10(6/7), 512-521.

O'Neil, J. M., \&Wrightsman, L. S. (2001). The mentoring relationship in psychology training programs.

Orpen, C. (1995). The effects of mentoring on employees' career success.The journal of social psychology, 135(5), 667-668.

Perks, P. S., \& Oosthuizen, N. (2013). Exploring Supplier Negotiation Best Practices and Supplier Relationships Strategies in South Africa. Review of Integrative Business and Economics Research, 2(1), 333.

Pett, T. L., \& Wolff, J. A. (2011, January). SME Identity and Homogeneity-Are There Meaningful Differences Between Micro, Small, and Medium-Sized Enterprises?. In ICSB World Conference Proceedings (p. 1). International Council for Small business (ICSB).

Pompa, C. (2012). Literature Review on enterprise mentoring. ODI, UK. Available at http://www.forsamena. org/fr/content/documents/Literature\% 20review\% 20on\% 20enterprise\% 20mentoring. pdf (accessed 3 October 2013).

Pratono, A. H., \& Mahmood, R. (2014). Social Capital and Firm Performance: Moderating Effect of Environmental Turbulence. Asian Social Science, 10(19), 59.

Ragins, B. R., \& Cotton, J. L. (1999). Mentor functions and outcomes: a comparison of men and women in formal and informal mentoring relationships. Journal of applied psychology, 84(4), 529.

Revelo, R. A., \& Loui, M. C. (2015). A Developmental Model of Research Mentoring. College Teaching, (just- accepted), 00-00.

Robinson, D. M., \&Reio Jr, T. G. (2012). Benefits of mentoring African-American men. Journal of Managerial Psychology, 27(4), 406-421.

Robinson, D. M., \&Reio Jr, T. G. (2012).Benefits of mentoring African-American men.Journal of Managerial Psychology, 27(4), 406-421.

Rockoff, J. E. (2008). Does mentoring reduce turnover and improve skills of new employees? Evidence from teachers in New York City (No. w13868). National Bureau of Economic Research.

Rodd, J. (2012). Leadership in early childhood. McGraw-Hill Education (UK).

Rosenbusch, N., Brinckmann, J., \& Bausch, A. (2011). Is innovation always beneficial? A meta-analysis of the relationship between innovation and performance in SMEs. Journal of business Venturing, 26(4), 441-457.

Russell, J. E., \& Adams, D. M. (1997). The changing nature of mentoring in organizations: An introduction to the special issue on mentoring in organizations. Journal of Vocational Behavior, 51(1), 1-14.

Sachdeva, S., \& Malhotra, K. (2015).Motivating Students-Essentials of Mentoring, Coaching \& Counseling: Operational Strategy.

Scandura, T. A. (1998). Dysfunctional mentoring relationships and outcomes. Journal of management, 24(3), 449- 467. 
Scarborough, N. M., \& Zimmer, T. W. (1994).Essentials of small business management.

Seevers, R. L. Mentoring Pre-Service Special Education Teachers: What do they want to Know and what do they need to Know?

Selladurai, R. (Ed.). (2014). Servant Leadership: Research and Practice: Research and Practice. IGI Global. Sherifat, Y. O. (2013). Gender Differentials in Factors Affecting Performance of Small-Scale Enterprises in Lagos State, Nigeria. Innovative Issues and Approaches in Social Sciences, 6(2), 21-39.

Shrivastava, P., \& Grant, J. H. (1985). Empirically derived models of strategic decision-making processes. Strategic Management Journal, 6(2), 97-113.

Smethem, L., \&Youens, B. (2007). Harnessing the mentoring power of staff other than subject mentors within schools: widening the interpretation of mentoring within initial teacher education.

Sok, P., O Cass, A., \&Sok, K. M. (2013). Achieving superior SME performance: Overarching role of marketing, innovation, and learning capabilities. Australasian Marketing Journal (AMJ), 21(3), 161-167. Son, S., \& Kim, D. Y. (2016). The role of perceived management support and trust in mentors on protégés ${ }^{\text {ee }}$ organizational citizenship behavior. Asia Pacific Journal of Human Resources.

Stam, W., Arzlanian, S., \&Elfring, T. (2014). Social capital of entrepreneurs and small firm performance: A meta- analysis of contextual and methodological moderators. Journal of Business Venturing, 29(1), 152-173.

St-Jean, E., \&Audet, J. (2009).Factors leading to satisfaction in a mentoring scheme for novice entrepreneurs.International journal of evidence based coaching and mentoring, 7(1), 148-161.

St-Jean, E., \&Audet, J. (2012). The role of mentoring in the learning development of the novice entrepreneur.International Entrepreneurship and Management Journal, 8(1), 119-140.

St-Jean, E., \& Tremblay, M. (2011). Opportunity recognition for novice entrepreneurs: The benefits of learning with a mentor. Academy of Entrepreneurship Journal, 17(2), 37-48.

Subhan, Q. A., Mehmood, M. R., \&Sattar, A. (2013, January).Innovation in Small and Medium Enterprises (SMEees) and its impact on Economic Development in Pakistan. In Paper was presented in 6th International Business and Social Sciences Research Conference, 3-4.

Swap, W., Leonard, D., Shields, M., Abrams, L. (2001) Using Mentoring and Storytelling to Transfer Knowledge in the Workplace. Journal of Management Systems, 18, 1, 95-114.

Teeratansirikool, L., Siengthai, S., Badir, Y., \&Charoenngam, C. (2013). Competitive strategies and firm performance: the mediating role of performance measurement. International Journal of Productivity and Performance Management, 62(2), 168-184.

Tracy, K., Burton, M., Warren, M., Guzman, D., Galanter, M., Babuscio, T., \&Nich, C. (2015). Predictors of substance use outcomes in mentorship for addiction problems. Drug \& Alcohol Dependence, 146, e7.

Uy, M. A., Foo, M. D., \& Song, Z. (2013).Joint effects of prior start-up experience and coping strategies on entrepreneurse ${ }^{\text {ee }}$ psychological well-being.Journal of Business Venturing, 28(5), 583-597.

Vickerstaff, S. (2007). I was just the boy around the place: What made apprenticeships successful? Journal of Vocational Education and Training, 59(3), 331-347.

Weng, R. H., Huang, C. Y., Tsai, W. C., Chang, L. Y., Lin, S. E., \& Lee, M. Y. (2010). Exploring the impact of mentoring functions on job satisfaction and organizational commitment of new staff nurses. BMC Health Services Research, 10(1), 1.

Wisker, G., Exley, K., Antoniou, M., \& Ridley, P. (2013). Working one-to-one with students: supervising, coaching, mentoring, and personal tutoring. Routledge.

Zhu, Y., Wittmann, X., \& Peng, M. W. (2012).Institution-based barriers to innovation in SMEs in China.Asia Pacific Journal of Management, 29(4), 1131-1142. 
